\title{
2016年台風10号をモデルとした 内浦湾における潮位偏差の発生特性
}

南 翔 1 ・ 工藤 圭太 1 ・八木澤 一城 2 橋本 孝治 2 ・渡部 靖憲3

\author{
1非会員＼cjkstart株式会社アルファ水エコンサルタンツ＼cjkstart技術部 \\ ( ( 063-0829 札幌市西区発寒9条14丁目516-336) \\ E-mail:minami@ahec.jp \\ 2正会員 株式会社アルファ水エコンサルタンツ 技術部 \\ ( ○063-0829 札幌市西区発寒9条14丁目516-336) \\ 3 正会員 博(工) 北海道大学准教授 大学院工学研究院 $(\bar{T} 060-8628$ 札幌市北区北13 条西 8 丁目)
}

\begin{abstract}
2016年台風10号は従来と異なる複雑な経路をたどり, 東北地方を北西に移動し, 日本海へと進行した. この台風により北海道内浦湾では高潮が発生し，台風による吹送流と強風により大きな漁業被害をうけた． このような前例のない経路を辿った台風での検討は重要である，そこで，本研究では，台風モデルと非線 形長波モデルを使用した高潮計算を行った。本台風をモデルとし, 想定されうる8 コースで高潮計算を行 い，内浦湾での潮位偏差の発生特性を解明寸るとともに，危険に作用寸る経路を推測した．さらに，『高 潮浸水想定区域図作成の手引き(国土交通省)』に基づく, 想定台風による試算を行い, 今後の内浦湾沿岸 での浸水想定における知見を得た。
\end{abstract}

Key Words : storm surge, Uchiura Bay, numerical simulation, tyhoon model, inundation prediction

\section{1. はじめに}

平成 27 年の水防法改定に伴い，都道府県には「高潮 浸水想定区域図作成の手引き」)(以降「手引き」)をもと に，浸水想定区域図を作成することとされた。この浸水 想定においては，既往最大クラスの台風が各海岸で最大 潮位偏差をもたらす経路を通過した場合を想定すること とされている.この検討に際し，各海岸における高潮特 性を把握することが重要となる.

ここで, 既往の検討では歴史的に高潮の被害の多い三 大湾を対象に最大クラスの台風を用いた高潮の浸水想定 が多く行われている223. 一方で、北海道では 2014年お よび2015 年に発生した低気圧による根室地方での高潮 をモデルとした研究がされている收が，勢力を保ったま ま北海道に台風が接近することは稀であり, 北海道の台 風による高潮を検討した事例は少ない，

ところが，2016年8月に発生した台風10号は従来の台 風とは異なる複雑なコースを辿り北海道南西部を通過し た(図-1)。これは，今まで北海道に接近した台風には例 の無い異常なコースであった.この台風により北海道内 浦湾(図-2)では，高潮による浸水被害は発生しなかった ものの吹送流と強風によって増養殖施設などの浮体式構 造物を中心に大きな漁業被害が発生した。

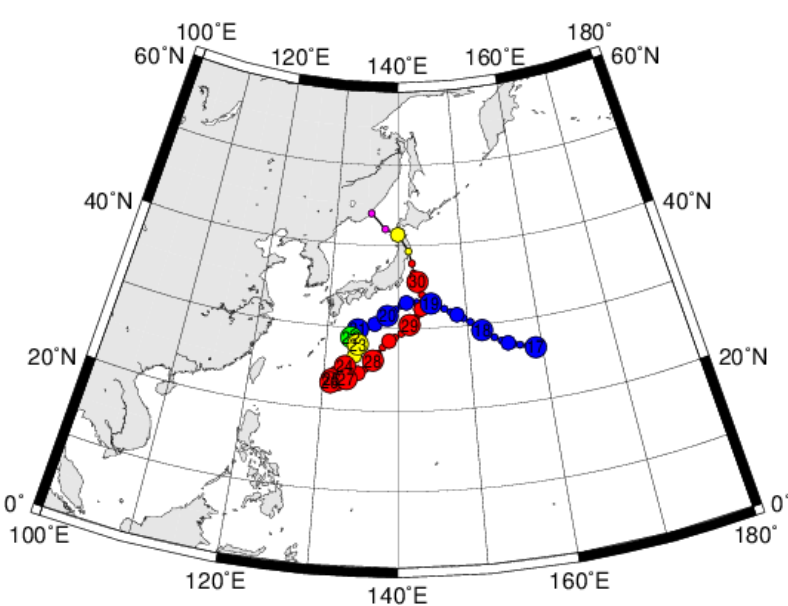

図-1 台風10号の経路

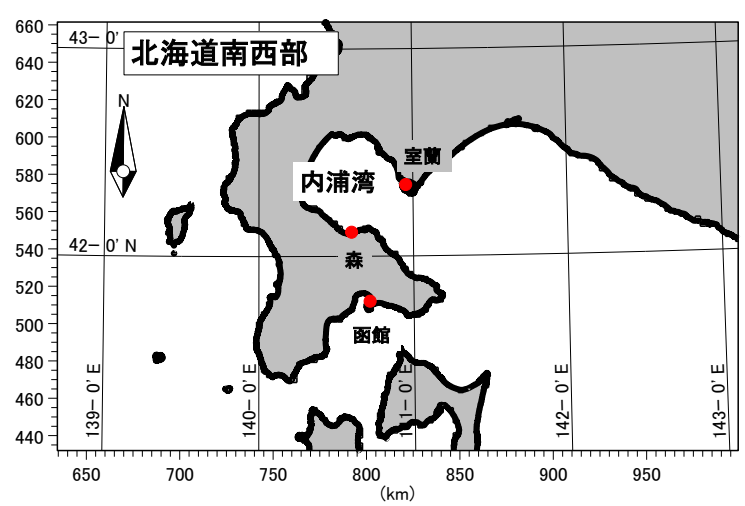

図-2 位置図 
表-1 台風による潮位偏差の上位 5 事象

\begin{tabular}{|c|c|c|c|c|c|c|}
\hline \multirow[b]{2}{*}{ No } & \multirow[b]{2}{*}{ 年月日 } & \multirow[b]{2}{*}{$\begin{array}{l}\text { 台 } \\
\text { 風 }\end{array}$} & \multicolumn{2}{|c|}{ 室蘭 } & \multicolumn{2}{|c|}{ 森 } \\
\hline & & & $\begin{array}{c}\text { 潮位偏差 } \\
\text { (cm) }\end{array}$ & 起時 & $\begin{array}{c}\text { 潮位偏差 } \\
(\mathrm{cm})\end{array}$ & 起時 \\
\hline 1 & $2002 / 10 / 2$ & 21 号 & 65 & 15:00 & 51 & $\begin{array}{c}3: 00 \\
15: 00 \\
\end{array}$ \\
\hline 2 & $2004 / 8 / 20$ & 15号 & 54 & 5:00 & 44 & 5:00 \\
\hline 3 & $2004 / 8 / 31$ & 16号 & 70 & 20:00 & 61 & $20: 00$ \\
\hline 4 & $2004 / 9 / 8$ & 18号 & 64 & $\begin{array}{l}7: 00 \\
8: 00 \\
\end{array}$ & 41 & 2:00 \\
\hline 5 & $2006 / 9 / 19$ & 13号 & 56 & 20:00 & 43 & $20: 00$ \\
\hline & $2016 / 8 / 30$ & 10号 & 64 & 23:00 & 49 & 23:00 \\
\hline
\end{tabular}

表-2 台風のパラメータ

\begin{tabular}{|c|c|c|c|c|c|c|c|}
\hline No & 年月日 & 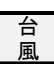 & $\begin{array}{c}\text { 中心気圧 } \\
(\mathrm{hPa})\end{array}$ & $\begin{array}{c}\text { 暴風域半径 } \\
(\mathrm{km})\end{array}$ & $\begin{array}{c}\text { 最大風速 } \\
(\mathrm{m} / \mathrm{s})\end{array}$ & 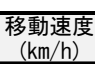 & 時刻 \\
\hline 1 & $2002 / 10 / 2$ & 21号 & 980 & 110 & 30 & 65 & $6: 00$ \\
\hline 2 & $2004 / 8 / 20$ & 15号 & 980 & 90 & 30 & 53 & $8: 00$ \\
\hline 3 & $2004 / 8 / 31$ & 16号 & 975 & 190 & 30 & 85 & $12: 00$ \\
\hline 4 & $2004 / 9 / 8$ & 18号 & 970 & 150 & 30 & 42 & $6: 00$ \\
\hline 5 & 2006/9/19 & 13号 & 992 & - & - & 28 & $21: 00$ \\
\hline & $2016 / 8 / 30$ & 10号 & 972 & 220 & 30 & 75 & 21:00 \\
\hline
\end{tabular}

一般的に南側に開いた湾では，台風による高潮被害が 発生しやすいとされ，内浦湾は湾口が南東に開いている ことから，比較的高潮の被害が大きくなりやすい地形で あるといえる、また，内浦湾では湾口に位置する森・室 蘭で潮位観測が行われているものの，これら以外には観 測所がなく具体的な潮位の変動についは不明であり，同 湾での潮位偏差の発生特性を解明することは重要である.

そこで, 本研究では, 台風10号をモデルとし, 想定し た8コースで潮位偏差を数值計算によって予測し, 内浦 湾における潮位偏差の発生特性を解明した.

\section{2016年台風10号の概要}

2016年台風10号は，2016年8月21日に台風に発達し， 困-1に示す複雑な経路を通り，太平洋側を北上し8月30 日18時ごろ岩手県大船渡市に上陸した。その後，台風は 東北地方を北西に移動し，8月31日0時に日本海で温帯低 気圧に変わった. この台風が内浦湾に接近した時の中心 気圧は $972 \mathrm{hPa}$ ，暴風域の半径は $220 \mathrm{~km}$, 最大風速は $30 \mathrm{~m} / \mathrm{s}$ であった。また、この台風による潮位偏差は室蘭で $64 \mathrm{~cm}$, 森で49cmであった(暫定值).

室蘭での過去20年の潮位観測結果を整理し，台風によ る潮位偏差の上位 5 事象を抽出し，森での潮位観測結果 とともに整理した(表-1). また，これらの台風および 2016年台風10号の経路を図-3に，内浦湾接近時の台風の パラメータを表-2に示す.

表-1より，本台風による潮位偏差は，上位3位に入る ものであることが確認できる，また，表-2より，台風半

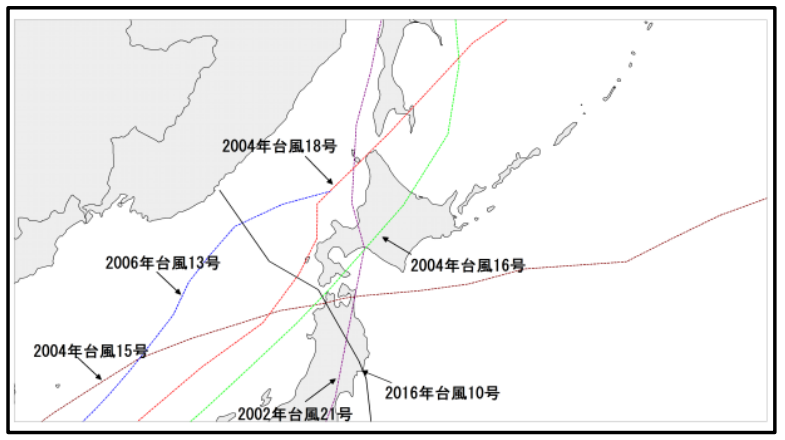

図-3 台風の経路の一覧図

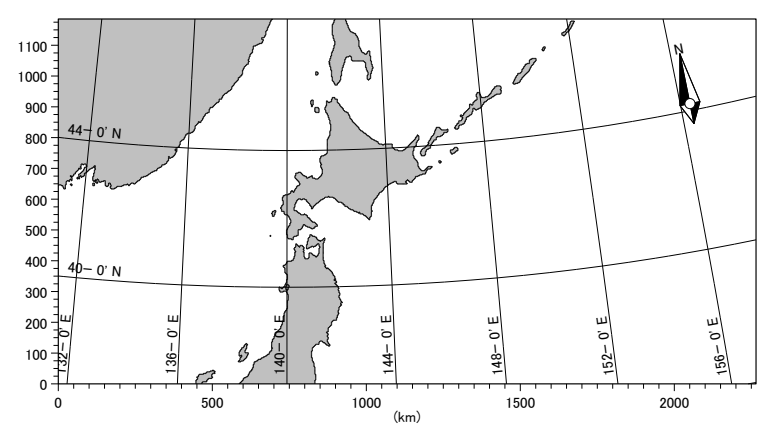

図-4 計算領域図

径および最低気圧も抽出した台風と比較して，上位に入 るものであることがわかる．なお、「手引き」の想定台 風の移動速度は73km/hとされており、2004年16号と2016 年10号以外はこれより遅い值であった。

ここで，図-3に示すとおり，これらの台風の経路は， 概ね南西から北東へと移動するものであり，2016年台風 10号のような太平洋側から北西に進行し湾の西側を通過 する経路は極めて異常であるといえる.

以上から，台風10号は従来の台風とは経路が大幅に異 なる台風である。このような前例のない経路での想定を 行うことは，今後の浸水想定などで非常に重要である.

\section{3. 計算条件}

本検討では，台風 10 号の再現計算を行い計算モデル の妥当性を確認した上で，同台風をモデルとし 8 コース を想定した。これらのコースで高潮計算を実施し, 内浦 湾における潮位偏差の発生特性を考察した.さらに，既 往最大クラスの台風が台風 10 号をもとに想定した 8 経 路を通った場合を想定し「手引き」による想定台風での 高潮計算を実施し, 湾内の潮位偏差を整理した。

\section{(1) 計算モデル}

外力とする気象条件は台風モデルを用いて作成し，高 潮計算は非線形長波モデルを使用した。計算領域を図-4 に示す、計算領域は，設定した8つの各経路で内浦湾で の高潮計算を十分に再現できる範囲とし，計算格子間隔 
表-3 検討ケースの一覧

\begin{tabular}{|c|c|c|c|c|c|}
\hline & 中心気 & $\begin{array}{l}\text { 台風 } \\
\text { 台風半 }\end{array}$ & $\begin{array}{l}\text { パラメータ } \\
\text { 最大風连 }\end{array}$ & 移動速度 & 台風の経路 \\
\hline 再現計算 & & 各時3 & 今の観測值 & & 実際の経路 \\
\hline CASE1 & $965 \mathrm{hPa}$ & $111 \mathrm{~km}$ & $33.2 \mathrm{~m} / \mathrm{s}$ & $58.0 \mathrm{~km} / \mathrm{h}$ & 経路1 \\
\hline CASE2 & $965 \mathrm{hPa}$ & $111 \mathrm{~km}$ & $33.2 \mathrm{~m} / \mathrm{s}$ & $58.0 \mathrm{~km} / \mathrm{h}$ & 経路2 \\
\hline CASE3 & $965 \mathrm{hPa}$ & $111 \mathrm{~km}$ & $33.2 \mathrm{~m} / \mathrm{s}$ & $58.0 \mathrm{~km} / \mathrm{h}$ & 経路3 \\
\hline CASE4 & $965 \mathrm{hPa}$ & $111 \mathrm{~km}$ & $33.2 \mathrm{~m} / \mathrm{s}$ & $58.0 \mathrm{~km} / \mathrm{h}$ & 経路4 \\
\hline CASE5 & $965 \mathrm{hPa}$ & $111 \mathrm{~km}$ & $33.2 \mathrm{~m} / \mathrm{s}$ & $58.0 \mathrm{~km} / \mathrm{h}$ & 経路5 \\
\hline CASE6 & $965 \mathrm{hPa}$ & $111 \mathrm{~km}$ & $33.2 \mathrm{~m} / \mathrm{s}$ & $58.0 \mathrm{~km} / \mathrm{h}$ & 経路6 \\
\hline CASE7 & $965 \mathrm{hPa}$ & $111 \mathrm{~km}$ & $33.2 \mathrm{~m} / \mathrm{s}$ & $58.0 \mathrm{~km} / \mathrm{h}$ & 経路7 \\
\hline CASE8 & $965 \mathrm{hPa}$ & $111 \mathrm{~km}$ & $33.2 \mathrm{~m} / \mathrm{s}$ & $58.0 \mathrm{~km} / \mathrm{h}$ & 経路8 \\
\hline CASE9 & $950 \mathrm{hPa}$ & $75 \mathrm{~km}$ & $60.0 \mathrm{~m} / \mathrm{s}$ & $58.0 \mathrm{~km} / \mathrm{h}$ & 経路1 \\
\hline CASE10 & $950 \mathrm{hPa}$ & $75 \mathrm{~km}$ & $60.0 \mathrm{~m} / \mathrm{s}$ & $58.0 \mathrm{~km} / \mathrm{h}$ & 経路2 \\
\hline CASE11 & $950 \mathrm{hPa}$ & $75 \mathrm{~km}$ & $60.0 \mathrm{~m} / \mathrm{s}$ & $58.0 \mathrm{~km} / \mathrm{h}$ & 経路3 \\
\hline CASE12 & $950 \mathrm{hPa}$ & $75 \mathrm{~km}$ & $60.0 \mathrm{~m} / \mathrm{s}$ & $58.0 \mathrm{~km} / \mathrm{h}$ & 経路4 \\
\hline CASE13 & $950 \mathrm{hPa}$ & $75 \mathrm{~km}$ & $60.0 \mathrm{~m} / \mathrm{s}$ & $58.0 \mathrm{~km} / \mathrm{h}$ & 経路5 \\
\hline CASE14 & $950 \mathrm{hPa}$ & $75 \mathrm{~km}$ & $60.0 \mathrm{~m} / \mathrm{s}$ & $58.0 \mathrm{~km} / \mathrm{h}$ & 経路6 \\
\hline CASE15 & $950 \mathrm{hPa}$ & $75 \mathrm{~km}$ & $60.0 \mathrm{~m} / \mathrm{s}$ & $58.0 \mathrm{~km} / \mathrm{h}$ & 経路7 \\
\hline CASE16 & $950 \mathrm{hPa}$ & $75 \mathrm{~km}$ & $60.0 \mathrm{~m} / \mathrm{s}$ & $58.0 \mathrm{~km} / \mathrm{h}$ & 経路8 \\
\hline
\end{tabular}

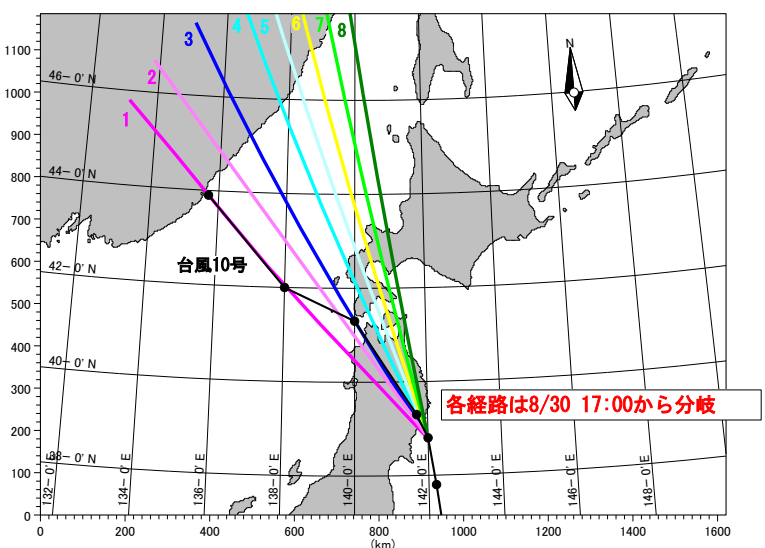

図-5 検討した台風の経路の一覧

は2700m，東西方向 $2268 \mathrm{~km} ，$ 南北方向 $1188 \mathrm{~km}$ とした。計 算期間は本台風が東北上陸前から日本海を通過し低気圧 に吸収され消滅するまでの2016年8月30日9:00～8月31日 9:00の24時間とした。また，計算間隔は3秒とした．外力 となる気圧・風はそれぞれ，Myersの式5)、Youngのらの式 を使用した。作成に当たっては3時間ごとの台風の座 標・中心気圧 ・半径・最大風速を入力し, 間の期間は内 挿してデータを作成した.

\section{(2) 台風の設定}

検討ケースの一覧を表-3に，検討した台風の経路を図 -5 に示す.

再現計算においては，経路および入力条件は気象庁べ ストトラックデータを基に作成した.

CASE1〜CASE8 では台風 10 号をモデル化した台風で 8 つの経路を設定し，高潮計算を行った。ここで，台風は 進行方向の右側で風速が速くなるため, 湾の左側を通過 する経路で吹送流の影響が強くなり，潮位偏差が高くな ることを想定し、湾の左側を通る経路を多く設定した. 具体的には，東北地方に上陸する直前の 8 月 30 日 17 時 から台風が日本海をへ出た経路を経路 1, 東北地方に上 陸しそのまま直進した経路を経路 3，上陸前の進行方向

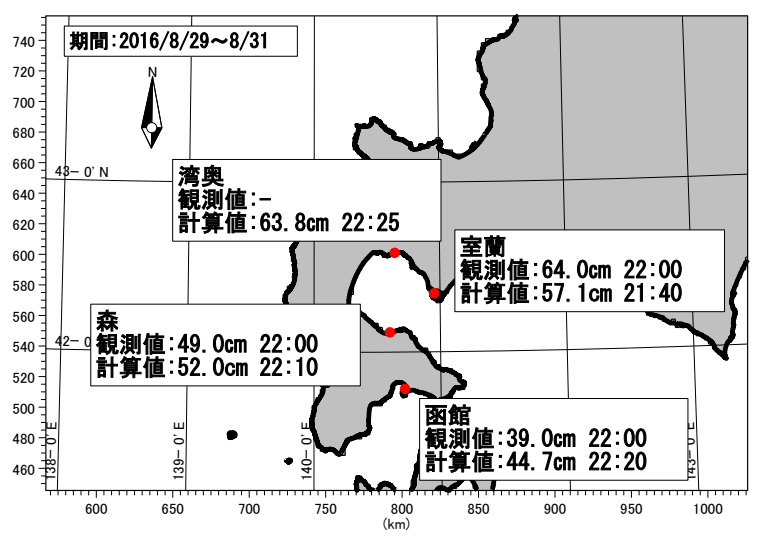

図-6 観測值(暫定) と再現計算による計算值

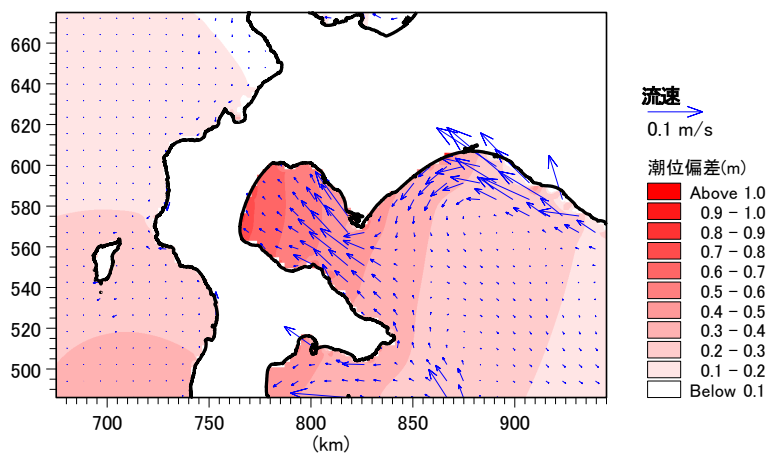

図-7 潮位偏差と流速ベクトル図(8月30日21:30)

をそのまま直進した経路を経路 8 とし，その間を分割し 8 つの経路を設定した. 経路 6 が内浦湾の中央を通過し, 経路 1 5は湾の左側, 経路 7, 8が湾の右側を通過する. また，台風のパラメータは東北地方に上陸直前の值のま ま一定として，8月30日 17 時の值を基に中心気圧 $965 \mathrm{hPa}$ 半径 $111 \mathrm{~km}$, 最大風速 $33.2 \mathrm{~m} / \mathrm{s}$ ，移動速度 $58 \mathrm{~km} / \mathrm{h}$ と設定 した.

CASE9 16 では，「手引き」に基づく既往最大クラス の台風が，台風 10 号をモデルとした前述の 8 つの経路 を辿った場合の高潮計算を実施した. ここで台風のパラ メータは「手引き」を参照し, 中心気圧 $950 \mathrm{hPa}$, 半径 $75 \mathrm{~km}$ ，最大風速 $60.0 \mathrm{~m} / \mathrm{s}$ とした. なお，今回の台風の経 路は従来のものと大きく異なるため, 台風の移動速度は CASE1 8 と同様に $58 \mathrm{~km} / \mathrm{h}$ とした.

\section{4. 台風 10 号の再現計算}

予測計算に先立ち，台風 10 号の再現計算を行い，本 計算モデルの妥当性を検証した.

2016 年 8 月 29 日〜 8 月 31 日での最大潮位偏差の観測 值と計算值および発生時刻を示す(図-6). 最大潮位偏差 とその発生時刻を比較したところ，最大潮位偏差は土 $10 \mathrm{~cm}$ 程度で，また発生時刻は土30 分程度で一致した。 この結果から，再現性は妥当であると判断した. この再 現計算の結果から，湾奥での最大潮位偏差は63.8cmであ り, 湾内で最大の偏差であった. 


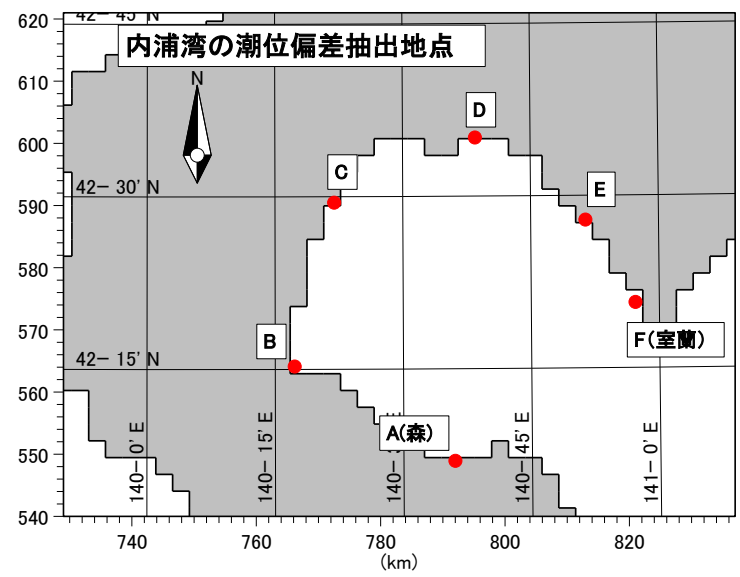

図-8 最大潮位偏差の抽出点

表-4 最大潮位偏差と発生時刻

\begin{tabular}{|c|c|c|c|c|c|c|c|}
\hline & & $\mathrm{A}($ 森) & $\mathrm{B}$ & $\mathrm{C}$ & $\mathrm{D}$ & $\mathrm{E}$ & F(室蘭) \\
\hline CASE1 & 最大偏差 & $47.1 \mathrm{~cm}$ & $\begin{array}{l}73.8 \mathrm{~cm} \\
\end{array}$ & $\begin{array}{ll}73.9 \mathrm{~cm} \\
\end{array}$ & (60cm & $\begin{array}{l}47.4 \mathrm{~cm} \\
\end{array}$ & "48.3cm \\
\hline & & $8 / 3023: 10$ & $8 / 3023: 05$ & $8 / 30 \quad 23: 45$ & $8 / 310: 05$ & $8 / 310: 10$ & $8 / 3023: 15$ \\
\hline CASE2 & $\begin{array}{l}\text { 最大偏差 } \\
\text { 登牛時刻 }\end{array}$ & $\begin{array}{c}52.2 \mathrm{~cm} \\
8 / 3023: 15\end{array}$ & $\begin{array}{c}80.6 \mathrm{~cm} \\
8 / 3022: 50\end{array}$ & $\begin{array}{c}92.1 \mathrm{~cm} \\
8 / 3023.45\end{array}$ & $\begin{array}{l}74.8 \mathrm{~cm} \\
8 / 310.05\end{array}$ & $\begin{array}{l}59.4 \mathrm{~cm} \\
8 / 310: 10\end{array}$ & $\begin{array}{c}62 \mathrm{~cm} \\
8 / 3023 \cdot 25\end{array}$ \\
\hline CASE3 & 最大偏差 & $59.8 \mathrm{~cm}$ & $86.6 \mathrm{~cm}$ & $99.8 \mathrm{~cm}$ & $91.8 \mathrm{~cm}$ & $74 \mathrm{~cm}$ & $82.2 \mathrm{~cm}$ \\
\hline & 発生時刻 & $8 / 3023: 10$ & $8 / 30 \quad 22: 55$ & $8 / 30 \quad 23: 45$ & $8 / 310: 00$ & $8 / 3023: 55$ & 8/30 23:20 \\
\hline CASE4 & 最大偏差 & $\begin{array}{c}65.7 \mathrm{~cm} \\
8 / 3022: 50\end{array}$ & $\begin{array}{c}74.6 \mathrm{~cm} \\
8 / 3022: 05\end{array}$ & $\begin{array}{c}71.1 \mathrm{~cm} \\
8 / 3023: 30\end{array}$ & $\begin{array}{l}75.2 \mathrm{~cm} \\
8 / 310: 25\end{array}$ & $\begin{array}{l}71.2 \mathrm{~cm} \\
8 / 310: 15\end{array}$ & $\begin{array}{c}76.5 \mathrm{~cm} \\
8 / 3023: 50\end{array}$ \\
\hline CASE5 & 最大偏着 & $\begin{array}{c}58.9 \mathrm{~cm} \\
8 / 3022: 30 \\
8\end{array}$ & $\begin{array}{c}66.2 \mathrm{~cm} \\
8 / 3021: 45\end{array}$ & $\begin{array}{c}62.1 \mathrm{~cm} \\
8 / 3023: 25\end{array}$ & $\begin{array}{l}60.7 \mathrm{~cm} \\
8 / 310: 15 \\
\end{array}$ & $\begin{array}{l}63.2 \mathrm{~cm} \\
8 / 310: 20 \\
\end{array}$ & $\begin{array}{l}62.7 \mathrm{~cm} \\
8 / 310: 05 \\
\end{array}$ \\
\hline CASE6 & $\begin{array}{l}\text { 最大偏差 } \\
\text { 発生時刻 }\end{array}$ & $\begin{array}{c}52.8 \mathrm{~cm} \\
8 / 3022: 25\end{array}$ & $\begin{array}{c}60.2 \mathrm{~cm} \\
8 / 3021: 40\end{array}$ & $\begin{array}{c}57.2 \mathrm{~cm} \\
8 / 3023: 45\end{array}$ & $\begin{array}{c}57.3 \mathrm{~cm} \\
8 / 3023: 50\end{array}$ & $\begin{array}{l}56.5 \mathrm{~cm} \\
8 / 310: 30\end{array}$ & $\begin{array}{c}58.4 \mathrm{~cm} \\
8 / 3023: 00\end{array}$ \\
\hline CASE7 & 最大偏差 & $\begin{array}{c}47 \mathrm{~cm} \\
8 / 3022: 30\end{array}$ & $\begin{array}{c}53.9 \mathrm{~cm} \\
8 / 3021: 40\end{array}$ & $\begin{array}{c}52.1 \mathrm{~cm} \\
8 / 3023: 35\end{array}$ & $\begin{array}{c}54.9 \mathrm{~cm} \\
8 / 3023: 45\end{array}$ & $\begin{array}{c}52.7 \mathrm{~cm} \\
8 / 3023: 30\end{array}$ & $\begin{array}{c}56.8 \mathrm{~cm} \\
8 / 3023: 10\end{array}$ \\
\hline CASE8 & $\begin{array}{l}\text { 最大偏着 } \\
\text { 発生時刻 }\end{array}$ & $\begin{array}{c}42.2 \mathrm{~cm} \\
8 / 3021: 25\end{array}$ & $\begin{array}{c}47.7 \mathrm{~cm} \\
8 / 3021: 40\end{array}$ & $\begin{array}{c}44.2 \mathrm{~cm} \\
8 / 3023: 25\end{array}$ & $\begin{array}{c}50.1 \mathrm{~cm} \\
8 / 3023: 35\end{array}$ & $\begin{array}{c}49.9 \mathrm{~cm} \\
8 / 3023: 20\end{array}$ & $\begin{array}{c}55.5 \mathrm{~cm} \\
8 / 3023: 05 \\
\end{array}$ \\
\hline
\end{tabular}

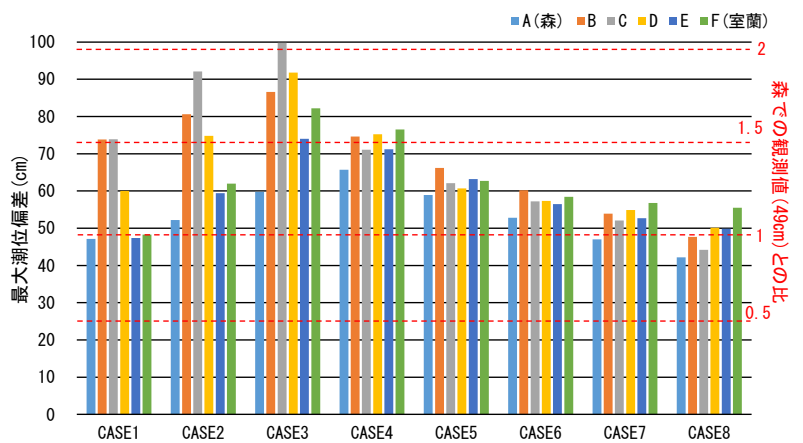

図-9 抽出点での経路ごとの最大潮位偏差

また，8月 30 日 21:30 を例として潮位偏差分布と流速 ベクトル図を示す(図-7). 図-7 より, 同時刻に湾口から の吹送流が卓越し潮位偏差が上昇した。この結果から， 2016 年台風 10 号では台風の接近に伴う南東の風によっ て，吹送流が卓越したと考える.

\section{5. 内浦湾での潮位偏差の発生特性}

台風 10 号の経路をもとに，上述の 8 コースで高潮計 算を行い内浦湾での潮位変化特性を考察した.

\section{(1) 計算結果}

潮位特性の変化を見るため, 観測所のある A 森・F室 蘭に加え, 内浦湾の西 $\mathrm{B}$, 北西 $\mathrm{C}$, 北 $\mathrm{D}$, 北東 $\mathrm{E} の 6$ 地 点での最大潮位偏差の整理を行った(図-8). 各点での最 大潮位偏差の一覧および森での観測值 $(49 \mathrm{~cm})$ との比を図-
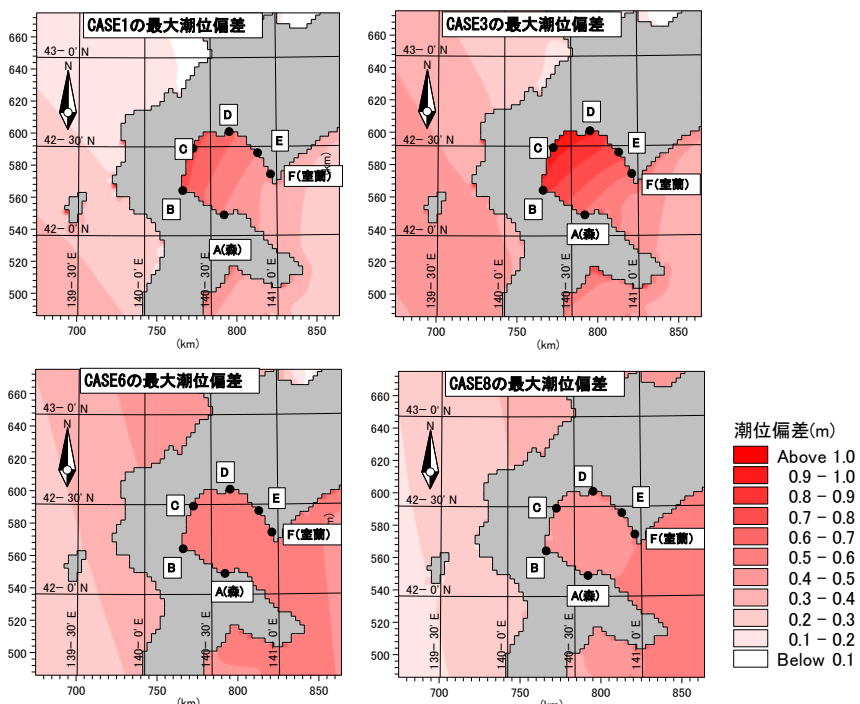

図-10 代表ケースでの最大潮位偏差分布図

9 に，最大潮位偏差とその発生時刻を表-4に示す.

\section{(2) 考察}

想定した $8 つ の$ 経路の最大潮位偏差の傾向を整理する. まず，湾の中央を通過する CASE6 での各地点の最大潮 位偏差は概ね $50 \mathrm{~cm}$ 程度であった。本検討で設定した台 風の中心気圧は965hPaなので，この潮位偏差は気圧によ る吸い上げだけで説明でき，この経路では吹送流による 吹き寄せの影響がほとんどないと考える，次いで，湾の 右側を通過する CASE7，8 での最大潮位偏差は, CASE6 と同程度であり，台風の経路が右にズレたため，気圧に よる吸い上げ効果が減少したと考える. 一方で湾の左側 を通過する CASE1 5 では，A では CASE4 で，B F では CASE3 で潮位偏差が最大となり，それより左側の経路 では最大潮位偏差が低くなっている(図-9). これは，A では CASE4 で，B F では CASE3 で吹送流による吹き寄 せが顕著に表れた結果であり, 経路が湾から離れたため 吹送流が弱まり最大潮位偏差が低下したと考えられる.

以上を整理すると想定した 8 経路では，湾の中央を通 過する CASE6 が吸い上げが最も顕著に表れた経路であ り，それより左側を通過する経路では吸い上げに加え， 吹送流による吹き寄せが発生し, 潮位偏差が増大寸る傾 向にある.これは図-10 に示す最大潮位偏差分布図から も確認できる. また，内浦湾全体で潮位偏差が高くなっ たのは CASE3 であり，この時に吹送流による吹き寄せ の影響が最も強くなり、潮位偏差が最大となったと考え る.これはモデルとした 2016 年台風 10 号が東北を通過 したまま直進した経路である。この時湾奥のCで潮位偏 差が最大となり $99.8 \mathrm{~cm}$ であった.

このCASE3の台風が内浦湾に接近した 8 月 30 日 22:30 の流速ベクトル図および風速分布図を図-11 に示す. 図11 より，この時に CASE3 では内浦湾の外から湾内に向 かう吹送流が卓越していることがわかる。 

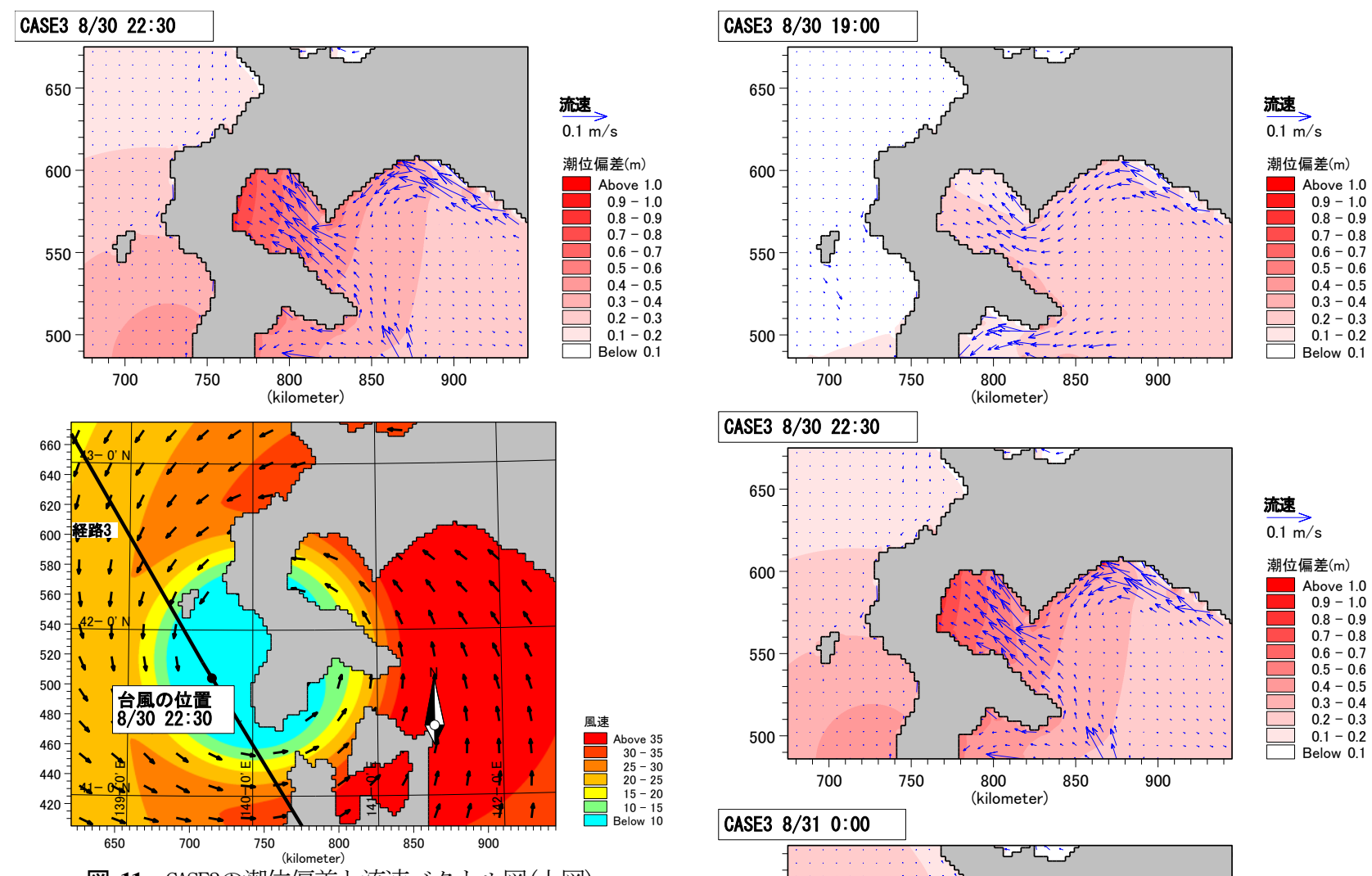

図-11 CASE3の潮位偏差と流速ベクトル図(上図) および風速分布図 (下図) (22:30)

この時, 図-11 より台風は湾口部での風速 $30 \mathrm{~m} / \mathrm{s}$ 程度で 南東から吹き込んでいることが確認できる．このとき台 風は湾の南西 $100 \mathrm{~km}$ 程度に位置していた。ここで本検討 で設定した台風の半径は $111 \mathrm{~km}$ であり, 風速が最も早く なる箇所が湾口に位置していたと考える. その結果,

CASE3 で吹送流が卓越し, 潮位偏差が大きくなったと 考える. 以上より, 台風の半径と経路が内浦湾の潮位偏 差に強い影響を与えていることが確認された。

次に、湾全体で潮位偏差が大きかった CASE3 を対象 に潮位偏差の発生特性を考察する. CASE3 の潮位偏差 と流速ベクトル図の時系列を図-12 に示寸。これより， 台風の接近に伴い，8月 30 日 19:00 に湾外から湾内一向 から吹送流が見られ，水位の上昇した．22:30 に台風は 湾の南西 $100 \mathrm{~km}$ 程度に位置しており, 湾口に南東の強風 が吹き込み, 吹送流が卓越し湾内での潮位偏差が急上昇 した．その後台風の移動に伴い，湾に南から風が吹き込 み, 湾の北側の C, D, Eでは 31 日 0:00 に最大值をとな った.この時には湾内から湾外に向かう流れが発生して おり(図-12)、これ以降は湾内の潮位偏差が低下した.

この結果から, CASE3 では, 台風の北上に伴う湾口 部での風向きの変化から, 湾の南 $\Rightarrow$ 西 $\Rightarrow$ 北の順に潮位偏 差が上昇することが判明した。

以上より，今回想定した 8 ケースで内浦湾の潮位偏差 が高かったのは，台風 10 号が東北を通過したまま直進 した経路であり，この時同台風による森での潮位偏差の 1.5 2 倍近い偏差が発生する. 参考として, 2 章で整理し

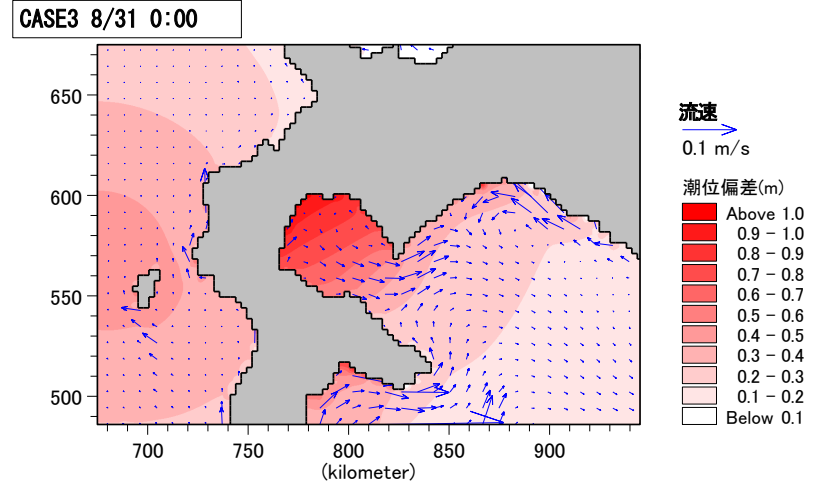

図-12 潮位偏差分布と流速ベクトル図 (CASE3)

た潮位観測結果と比較すると，本計算結果では森で 65.7 $\mathrm{cm}$, 室蘭で $82.2 \mathrm{~cm}$ であり台風による潮位偏差としては最 大となる.

\section{6. 最大規模の台風での高潮計算結果}

5 章で設定した 8 経路で「手引き」に基づく既往最大 クラスの想定台風での高潮計算を実施した.

ケースごとの最大潮位偏差および森での観測值 $(49 \mathrm{~cm})$ との比を図-13 に, 最大潮位偏差と発生時刻を表-5 に示 す. 図-13 と図-9より，本計算結果は前章での検討結果 之同様の傾向を示し，両端の経路で最大潮位偏差が低く， 湾の左側を通過する経路で最大であった。 また, 潮位偏 差が最大となったのはCASE11のCであり, 前章での検 討結果と同様であった $(205.7 \mathrm{~cm})$. しかし, CASE12 の D

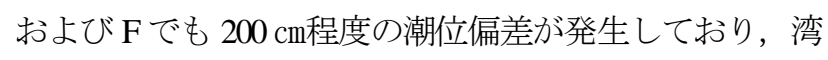
全体でみると CASE12 で潮位偏差が高く, 危険な経路で あった. この違いは, 設定した台風の半径が小さく, よ り湾に近い経路で吹き寄せが強くなるためと考える. 


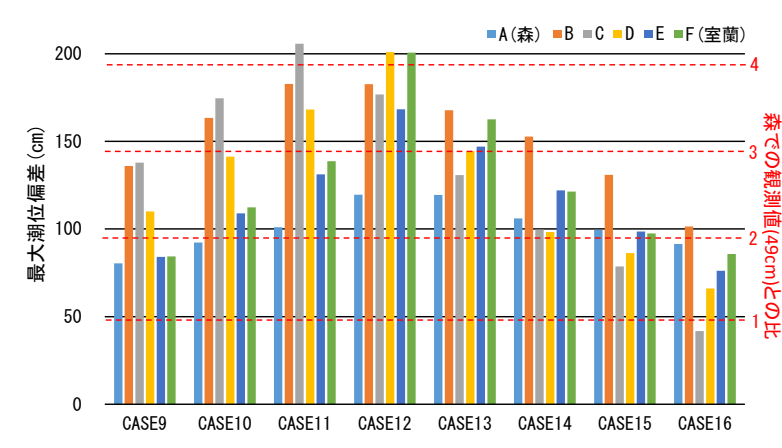

図-13 経路ごとの最大潮位偏差と観測值との比

表-5 想定台風での最大潮位偏差と発生時刻

\begin{tabular}{|c|c|c|c|c|c|c|c|}
\hline & & $\mathrm{A}($ 森) & $\mathrm{B}$ & $\mathrm{C}$ & $\mathrm{D}$ & $\mathrm{E}$ & F(室蘭) \\
\hline CASE9 & 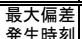 & $\begin{array}{l}80.4 \mathrm{~cm} \\
8 / 3023 \cdot 15\end{array}$ & $\begin{array}{l}135.9 \mathrm{~cm} \\
833023.00\end{array}$ & $\begin{array}{l}137.8 \mathrm{~cm} \\
8 / 3023 \cdot 50\end{array}$ & $\begin{array}{l}110 \mathrm{~cm} \\
8 / 310.05\end{array}$ & $\begin{array}{l}84.1 \mathrm{~cm} \\
8 / 310.05\end{array}$ & $\begin{array}{l}84.4 \mathrm{~cm} \\
8 / 3023 \cdot 30\end{array}$ \\
\hline CASE 10 & 戝大偏着刻 & $\begin{array}{r}92.3 \mathrm{~cm} \\
8 / 3023: 05 \\
\end{array}$ & $\begin{array}{c}163.4 \mathrm{~cm} \\
8 / 30 \quad 23: 00 \\
\end{array}$ & $\begin{array}{c}174.5 \mathrm{~cm} \\
8 / 3023: 45 \\
\end{array}$ & $\begin{array}{r}141.2 \mathrm{~cm} \\
8 / 310: 05 \\
\end{array}$ & $\begin{array}{r}108.9 \mathrm{~cm} \\
8 / 310: 10 \\
\end{array}$ & $\begin{array}{r}112.3 \mathrm{~cm} \\
8 / 3023: 30 \\
\end{array}$ \\
\hline CASE11 & $\begin{array}{l}\text { 最大偏厓 } \\
\text { 発生時刻 }\end{array}$ & $\begin{array}{c}101 \mathrm{~cm} \\
8 / 3022: 45 \\
\end{array}$ & $\begin{array}{r}182.7 \mathrm{~cm} \\
8 / 3022: 50 \\
\end{array}$ & $\begin{array}{r}205.7 \mathrm{~cm} \\
8 / 3023: 40 \\
\end{array}$ & $\begin{array}{r}168.1 \mathrm{~cm} \\
8 / 310: 00 \\
\end{array}$ & $\begin{array}{r}131.2 \mathrm{~m} \\
8 / 310: 05 \\
\end{array}$ & $\begin{array}{c}138.6 \mathrm{~cm} \\
8 / 3023: 30 \\
\end{array}$ \\
\hline CASE 12 & $\begin{array}{l}\text { 最大偏差 } \\
\text { 発生時刻 }\end{array}$ & $\begin{array}{c}119.6 \mathrm{~cm} \\
8 / 3023: 00\end{array}$ & $\begin{array}{c}182.6 \mathrm{~cm} \\
8 / 3022: 20\end{array}$ & $\begin{array}{c}176.7 \mathrm{~cm} \\
8 / 3022: 45 \\
\end{array}$ & $\begin{array}{c}200.9 \mathrm{~cm} \\
8 / 3023: 55\end{array}$ & $\begin{array}{c}168.3 \mathrm{~cm} \\
8 / 3023: 45 \\
\end{array}$ & $\begin{array}{c}200.7 \mathrm{~cm} \\
8 / 3023: 20\end{array}$ \\
\hline CASE & 最大偏差 & $\begin{array}{c}119.4 \mathrm{~cm} \\
8 / 3022: 50\end{array}$ & $\begin{array}{c}167.8 \mathrm{~cm} \\
8 / 3022: 05\end{array}$ & $\begin{array}{c}130.7 \mathrm{~cm} \\
8 / 3022: 20\end{array}$ & $\begin{array}{c}144.4 \mathrm{~cm} \\
8 / 310: 10\end{array}$ & $\begin{array}{c}147 \mathrm{~cm} \\
8 / 3023: 55\end{array}$ & $\begin{array}{c}162.6 \mathrm{~cm} \\
8 / 3023: 40\end{array}$ \\
\hline CASE 14 & 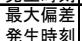 & $\begin{array}{c}106 \mathrm{~cm} \\
8 / 3021 \cdot 50\end{array}$ & $\begin{array}{r}152.7 \mathrm{~cm} \\
8 / 3022.05\end{array}$ & $\begin{array}{c}99.6 \mathrm{~cm} \\
8 / 3023 \cdot 25\end{array}$ & $\begin{array}{l}98.3 \mathrm{~cm} \\
8 / 3023.35\end{array}$ & $\begin{array}{c}122 \mathrm{~cm} \\
8 / 310: 10\end{array}$ & $121.3 \mathrm{~cm}$ \\
\hline CASE 15 & $\begin{array}{l}\text { 龺生大偏刻着 } \\
\text { 発生時刻 }\end{array}$ & $\begin{array}{l}8 / 7021.50 \\
99.5 \mathrm{~cm} \\
8 / 3021: 50\end{array}$ & $\begin{array}{c}8 / 130.9 \mathrm{~cm} \\
8 / 3022: 05\end{array}$ & $\begin{array}{c}78.6 \mathrm{~cm} \\
8 / 3023: 20 \\
\end{array}$ & $\begin{array}{c}86.3 \mathrm{~cm} \\
8 / 3023: 30 \\
\end{array}$ & $\begin{array}{c}8 / 310.10 \\
88.6 \mathrm{~cm} \\
8 / 310: 05\end{array}$ & $\begin{array}{l}97.5 \mathrm{~cm} \\
8 / 3022: 35 \\
\end{array}$ \\
\hline CASE 16 & $\begin{array}{l}\text { 最大偏差 } \\
\text { 発生時刻 }\end{array}$ & $\begin{array}{c}91.4 \mathrm{~cm} \\
8 / 3021: 50\end{array}$ & $\begin{array}{c}101.4 \mathrm{~cm} \\
8 / 3022: 10\end{array}$ & $\begin{array}{c}41.8 \mathrm{~cm} \\
8 / 3021: 00\end{array}$ & $\begin{array}{c}66 \mathrm{~cm} \\
8 / 3023: 20\end{array}$ & $\begin{array}{c}76.1 \mathrm{~cm} \\
8 / 3022: 55\end{array}$ & $\begin{array}{c}85.7 \mathrm{~cm} \\
8 / 3022: 45\end{array}$ \\
\hline
\end{tabular}

本計算結果と森での観測結果と比較すると, 最も危険 な CASE12で，最大で4倍の偏差となった.

\section{7. まとめ}

2016年台風10号は，東北地方を北西へ進行する異常な 経路をたどった．この台風により内浦湾では台風では上 位5位に入る潮位偏差を引き起こし, 増養殖施設などの 浮体式構造物で大きな漁業被害をもたらした.

この台風を基に高潮計算を行い，台風モデルで再現可 能であることを確認した．また，同台風をモデル化し内 浦湾を対象に8経路で検討を行った結果, 台風が東北地
方を通過したまま直進した際，観測結果の 1.5 倍程度の 潮位偏差が発生し，湾奥では $100 \mathrm{~cm}$ 近い潮位偏差が発生 することが判明した．また，内浦湾での潮位偏差の発生 特性として, 湾口からの風が卓越寸る時に湾外からの吹 送流によって潮位偏差が増大寸ることを解明した。これ は、湾口に南東の風が吹きこむ場合であり、台風が湾の 左側を通過するときなどに起こる．2016年台風10号では 内浦湾の左側を通過し、湾口に南東の風が吹き込んでお り、まさに危険な経路であったといえる。さらに最大ク ラスの台風での試算結果から, 今回の3倍程度の潮位偏 差が発生する可能性を示した. 今後の内浦湾における高 潮浸水想定の実施に資する重要な知見を得た.

\section{参考文献}

1) 国土交通省: 高潮浸水想定区域図作成の手引き,2015

2）川崎浩司, 下川信也, 村上智一: 超巨大台風による伊 勢湾湾奥部における高潮浸水予測, 土木学会論文集 B2(海岸工学), Vol. 72, No. 2, I_211-I_216, 2016.

3) 涉谷容子, 中條壮大, 金洙列, 森 信人, 間瀬肇: 第二 室戸台風にもとづく大阪湾の高潮と浸水範囲におよ ぼす気候変動の感度評価, 土木学会論文集 B2(海岸工 学), Vol. 72, No. 2, I_217-I_222, 2016.

4) 猿渡带由未, 武江寿大, 渡部靖憲: 冬季の温帯低気圧 による高潮の統計的リスク評価, 土木学会論文集 B2(海岸工学), Vol.72, No. 2, I_247-I_252, 2016.

5) Myers,V A and Malkin W (1961) :Some properties of hurricane wind fields as deduced from trajectories, U.S. weather Bereau, National Hurricase Researh Project, Report 49.

6) Young, I.R. and Sobey, R.J. :The Numerical Prediction of Tropical Cyclone Wind-Waves, James Cook University of North Queensland, Townville, (Dept. of Civil \& Systems Eng., Research Bulletin No.CS20), 1981.

(2017.3.15 受付)

Tide deviation characteristics in Uchiura Bay modeled on Typhoon Lionlock (2016)

\section{Sho MINAMI, Keita KUDOU, Kazuki YAGISAWA, Koji HASHIMOTO, and Yasunori WATANABE}

Typhoon Lionlock (2016) followed a complicated route that was different from the conventional typhoon. Lionlock moved northwest of the Tohoku region, and proceeded to the Sea of Japan . the typhoon caused large fishery damage due to windward flow and strong winds in Hokkaido's Uchura Bay.it is very important to calcurate tide deviation occured by typhoon that followed a characteristic course. Therefore, in this study, numerical experiments using a typhoon model and nonlinear longwave model were performed. Using the Lionlock typhoon as a model, we calculated the storm surge of eight possible tracks, clarified the occurrence characteristics of the tide deviation in Uchiura Bay and estimated the damages along each track. Further, we made calculations for creating a tidal flooded immersion area map (Ministry of Land, Infrastructure and Transport), and obtained knowledge on measures to use against storm surges along the coast of Uchiura Bay in the future. 